\title{
Primary gastric lymphoma of MALT: Considerations of pathogenesis, diagnosis and therapy
}

\author{
Wolfgang Fischbach MD PhD
}

W Fischbach. Primary gastric lymphoma of MALT: Considerations of pathogenesis, diagnosis and therapy. Can J Gastroenterology 2000;14(Suppl D):44D-50D. Primary gastric lymphoma of mucosa-associated lymphoid tissue (MALT) is a distinct entity with its own histological classification. Epidemiological, histomorphological, molecular biological and experimental data clearly underline that infection of the gastric mucosa by Helicobacter pylori plays an important role in both the development and progression of MALT lymphoma. Considering the histological grade of malignancy and dissemination (stage) of the disease as decisive prognostic factors, and therapeutic determinants, endoscopic bioptical diagnosis and endoscopic ultrasound are of particular importance. In cases of localized (stage 1), low grade lymphoma, eradication of $\mathrm{H}$ pylori offers a promising and fascinating therapeutic option. Surgical resection, radiotherapy or chemotherapy, and their combination, have proven to be effective treatment modalities. There is a need to clarify whether operative or conservative therapeutic strategies should be favoured in the future.

Key Words: Diagnosis; Gastric lymphoma; MALT; Mucosaassociated lymphoid tissue; Pathogenesis; Therapy

\section{Lymphome gastrique primitif du MALT : pathogenèse, diagnostic et traitement}

RÉSUMÉ : Le lymphome gastrique primitif du tissu lymphoïde associé aux muqueuses (MALT) forme une entité pathologique distincte et comporte sa propre classification histologique. Les données sur l'épidémiologie, l'histomorphologie, la biologie moléculaire et les essais montrent clairement que l'infection de la muqueuse gastrique par Helicobacter pylori joue un rôle important dans l'apparition et l'évolution du lymphome du MALT. Le degré histologique de malignité et la dissémination (stade) de la maladie constituent des facteurs pronostiques décisifs. Les déterminants thérapeutiques du diagnostic biopsique endoscopique et de l'échographie endoscopique revêtent également une grande importance. Dans les cas de lymphome circonscrit (stade I), peu malin, l'éradication de H. pylori offre une solution intéressante et prometteuse. La résection chirurgicale, la radiothérapie et la chimiothérapie, ou leur association, s'avèrent des moyens efficaces de traitement. Toutefois, on ne sait pas encore quelles stratégies il faudrait privilégier à l'avenir : la chirurgie ou le traitement conservateur.

\begin{abstract}
A bout $40 \%$ of all non-Hodgkin's lymphoma arise from an extranodal origin. Although many specifics in its clinical presentation and biological behaviour have become evident, extranodal lymphoma in general, and primary gas-
\end{abstract}

trointestinal lymphoma in particular, have been typed according to classification systems established for nodal lymphoma (Rappaport, Kiel, Working Formulation, etc) for decades. This has made comparing clinical data difficult or

This mini-review was prepared from a presentation made at the 1998 World Congress of Gastroenterology, Vienna, Austria, September 6 to 11, 1998 Medizinische Klinik II, Klinikum Aschaffenburg, Am Hasenkopf, Aschaffenburg

Correspondence and reprints: Prof Dr Wolfgang Fischbach, Medizinische Klinik II, Klinikum Aschaffenburg, Am Hasenkopf, D-63739

Aschaffenburg. Telephone +49-6021-323010, fax +49-6021-323031, wolfgang.fischbach@klinikum-aschaffenburg.de

Received for publication February 4, 1999. Accepted February 5, 1999 
even impossible, particularly because the definition of primary gastrointestinal lymphoma was not uniform.

\section{DEFINITION}

All prior definition criteria were exclusively based on the pattern of dissemination of the disease (1-3). Due to the outstanding work of Isaacson and Spencer (4) in the 1980s and the establishment of the concept of mucosa-associated lymphoid tissue (MALT), primary gastrointestinal lymphoma is now considered a distinct entity with its own histological classification (5) (Table 1). The vast majority of primary gastric lymphoma is B cell lymphoma of MALT (groups 1 and 2 of column 1 in Table 1), which can be identified by means of histopathological, immunohistochemical and cellular biological characteristics. Only in cases of high grade lymphoma without low grade components does the dissemination pattern have to be considered to separate widespread nodal disease, which secondarily involves the gastrointestinal tract (6). The revised European American classification of lymphoid neoplasms (REAL classification), which was proposed in 1994 (7) and is gaining importance, also lists B cell lymphoma of MALT as a distinct group (named extranodal marginal-zone B cell lymphoma). Now, for the first time, comparative analysis of international studies is feasible.

\section{PATHOGENESIS}

Gastrointestinal lymphoma is by far the most frequent manifestation of all extranodal lymphomas. Within the digestive tract, gastric lymphoma accounts for $70 \%$ or more of all lymphomas. This is surprising given that, contrary to the physio-
TABLE 1

Classification of gastrointestinal lymphoma

\begin{tabular}{ll}
\hline B cell NHL & \multicolumn{1}{c}{ T cell NHL } \\
\hline 1. Low grade NHL of MALT-type & $\begin{array}{l}\text { 1. Enteropathy-associated NHL } \\
\text { (enteropathy-associated } \\
\text { T cell NHL) }\end{array}$ \\
$\begin{array}{l}\text { 2. High grade NHL of MALT-type } \\
\text { with or without low grade } \\
\text { components }\end{array}$ & $\begin{array}{l}\text { 2. Other - Not } \\
\text { enteropathy-associated } \\
\text { NHL }\end{array}$ \\
$\begin{array}{l}\text { 3. Mediterranean type-NHL } \\
\text { 4. Multiple lymphomatous polyposis }\end{array}$ \\
$\begin{array}{l}\text { 5. Burkitt-type NHL } \\
\begin{array}{l}\text { 6. Other - Neither low grade NHL } \\
\text { nor high grade NHL }\end{array}\end{array}$ \\
\hline
\end{tabular}

MALT Mucosa-associated lymphoid tissue; NHL Non-Hodgkin's lymphoma. Data from reference 5

logical MALT of the small and large bowel, no lymphatic tissue occurs in the normal mucosa. This finding raises questions about the origin of acquired MALT and potential preneoplastic conditions. In the late 1980s, acquisition of intramucosal lymph follicles and accumulation of immunoglobulin A-producing plasma cells were discovered to result from Helicobacter pylori infection of the gastric mucosa (8-10). This acquired lymphatic tissue showed morphological characteristics of MALT and regressed after successful eradication of the bacterium (11). In 1991, Wotherspoon et al (12) demonstrated for the first time that patients with primary gastric MALT lymphoma are regularly infected by

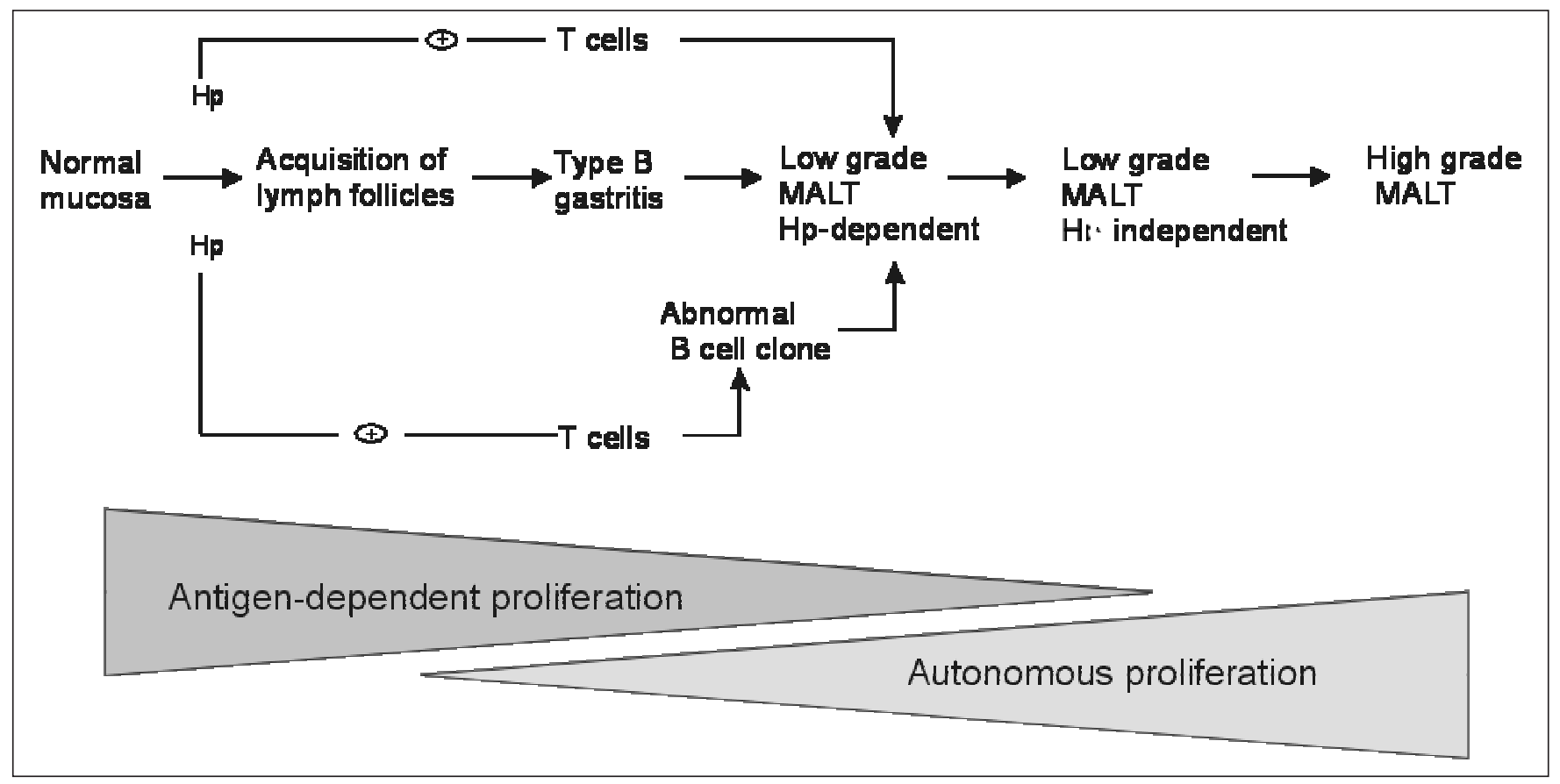

Figure 1) Considerations on the pathogenesis and progression of gastric mucosa-associated lymphoid tissue (MALT) lymphoma. Hp Helicobacter pylori 
TABLE 2

The Musshoff classification and its modification by Radaszkiewicz et al (26) for stage El

\begin{tabular}{|c|c|}
\hline Stage & Description \\
\hline Stage El1 & $\begin{array}{l}\text { Unifocal or multifocal involvement of the gastric } \\
\text { mucosa and submucosa without lymph node } \\
\text { involvement or infiltration of neighbouring organs }\end{array}$ \\
\hline Stage El2 & $\begin{array}{l}\text { As El1, but the lymphoma extends beyond the } \\
\text { submucosa }\end{array}$ \\
\hline Stage Ell1 & $\begin{array}{l}\text { Gastric involvement with infiltration of regional lymph } \\
\text { nodes; any depth of lymphoma infiltration }\end{array}$ \\
\hline Stage EII2 & $\begin{array}{l}\text { As Ell1, but additional involvement of nonregional } \\
\text { infradiaphragmatic lymph nodes }\end{array}$ \\
\hline Stage EIII & $\begin{array}{l}\text { Gastric involvement regardless of depth of infiltration; } \\
\text { additional involvement of regional and } \\
\text { nonregional infradiaphragmatics and } \\
\text { supradiaphragmatics }\end{array}$ \\
\hline Stage EIV & $\begin{array}{l}\text { Gastric involvement regardless of depth of infiltration; } \\
\text { additional involvement of regional and } \\
\text { nonregional infradiaphragmatic and } \\
\text { supradiaphragmatic lymph nodes, and diffuse or } \\
\text { disseminated involvement of extragastric organs }\end{array}$ \\
\hline
\end{tabular}

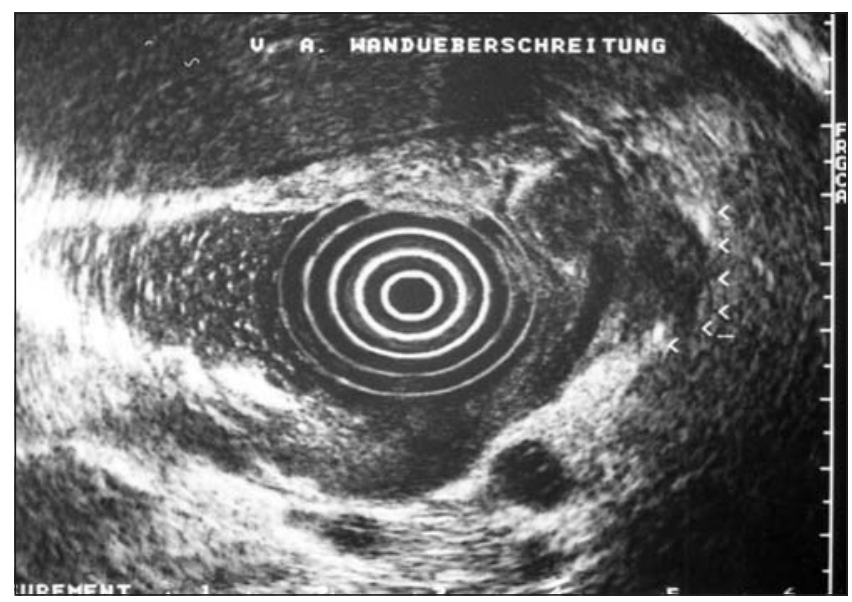

Figure 2) Endoscopic ultrasound showing extension of the lymphoma beyond the organ per continuitatem

H pylori. This finding has been confirmed by other investigators $(13,14)$. In addition to histomorphological studies, recent epidemiological $(15,16)$, molecular biological (17-19) and experimental $(20,21)$ data clearly indicate that $\mathrm{H}$ pylori plays a decisive role in the development and progression of gastric MALT lymphoma. Figure 1 summarizes current concepts of the pathogenesis of this lymphoma. The initial antigen-dependent proliferation is of major importance for an antibiotic treatment approach, as is discussed later. As long as antigen-driven tumour proliferation is evident, successful elimination of this stimulus may be followed by regression of the lymphoma. There is a need, however, to identify the parameters for the progression from $\mathrm{H}$ pylori-dependent lymphoma to autonomous tumour growth. The recent finding of $t(11 ; 18)(\mathrm{q} 21 ; \mathrm{q} 21)$ chromosome translocation may be a preliminary step toward this effort (22). It

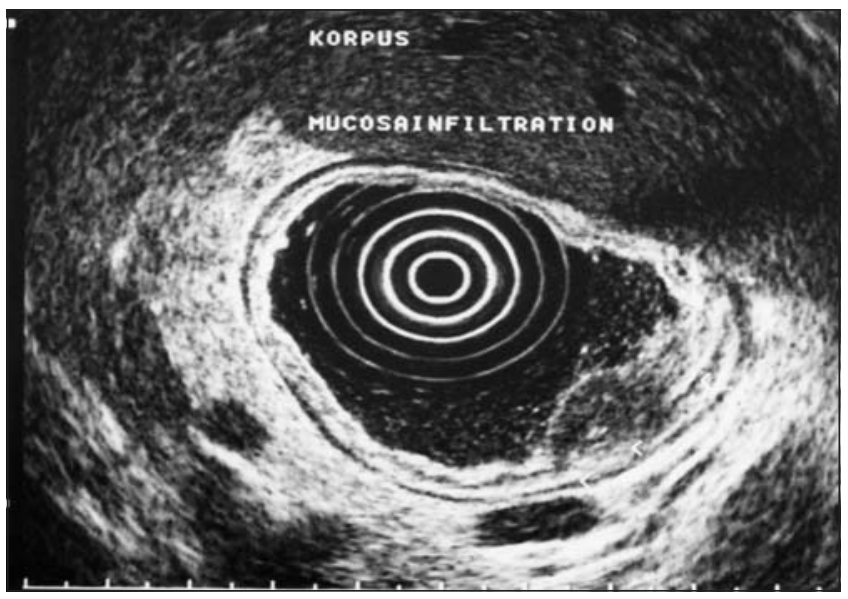

Figure 3) Endoscopic ultrasound of a gastric lymphoma restricted to the mucosa

may be assumed that high grade transformation does not always follow the sequence described (Figure 1). The frequency of de novo blastic, high grade lymphoma is still unknown. Also, other microorganisms may be of potential pathogenetic importance. Stolte et al (23) recently reported on a possible association of Helicobacter heilmannii with gastric MALT lymphoma. This consideration is also supported by findings of lymphoma regression in some serologically and histologically $\mathrm{H}$ pylori-negative individuals following usual anti-H pylori, anti-infectious therapy (24).

\section{DIAGNOSIS AND \\ CLINICAL STAGING PROCEDURES}

The first two studies, which based their retrospective analysis of large populations on the MALT classification, clearly identified malignancy (low grade versus high grade) and stage as the two major prognostic factors and therapeutic determinants $(25,26)$. Endoscopic biopsies and endoscopic ultrasounds are, therefore, of particular importance to diagnose, classify and stage gastric lymphoma reliably, especially if primary conservative therapy is favoured and pathohistological evaluation of the resected specimen is not available. Potential problems of endoscopic bioptic diagnoses are based on:

- the unspecific macroscopic appearance of the lymphoma (27);

- a submucosal growth pattern without visible changes;

- the multilocality of the lymphoma;

- the possibility of high malignant transformation arising focally; and

- a sampling error due to few and/or not representative specimens.

These theoretical considerations may be confirmed by the results of a study that compared the accuracy of endoscopic biopsies with the definite diagnosis of the gastrectomy specimens by the same reference pathologist (28). The dis- 
TABLE 3

Helicobacter pylori eradication therapy in low grade gastric mucosa-associated lymphoid tissue (MALT) lymphoma: Review of the literature

\begin{tabular}{|c|c|c|c|c|c|}
\hline Author (reference) & Year & Patients (n) & $\begin{array}{c}\text { Complete regression } \\
\text { of lymphoma (n) }\end{array}$ & Follow-up (months) & Relapse (n) \\
\hline Wotherspoon et al (33) & 1993 & 6 & 5 & 15 & 0 \\
\hline Weber et al (34) & 1994 & 1 & 1 & 9 & \\
\hline Pesch et al (35) & 1994 & 1 & 1 & & \\
\hline Fetscher et al (36) & 1995 & 1 & 0 & & \\
\hline Cammarota et al (37) & 1995 & 1 & 1 & 18 & 1 \\
\hline Bayerdörffer et al (38) & 1995 & 33 & 23 & 12 & 0 \\
\hline Morgner et al (39) & 1998 & 125 & 100 & 19 & Not indicated \\
\hline Roggero et al (40) & 1995 & 26 & 15 & 12 & 1 \\
\hline Savio et al (41) & 1995 & 15 & 13 & 23 & 0 \\
\hline Carlson et al (42) & 1996 & 1 & 1 & 15 & 1 \\
\hline Montalban et al (43) & 1997 & 9 & 8 & 14 & \\
\hline Tassinari et al (44) & 1997 & 1 & 1 & 36 & 0 \\
\hline Tsai et al (45) & 1997 & 3 & 3 & & \\
\hline Fischbach (28) & 1998 & 36 & 31 & 36.7 & 2 \\
\hline Nobre-Leitao et al (46) & 1998 & 17 & 17 & 2 & 2 \\
\hline
\end{tabular}

crepancies found in $26 \%$ of cases were caused mainly by overlooking low or high grade components in the biopsies. To improve this unsatisfactory situation, subtle endoscopic bioptic techniques are needed, including repeated biopsies and the use of large forceps in individual cases. The author favours gastric mapping, comprised of biopsies of all visible lesions and of normally appearing mucosa from the antrum $(n=4)$, corpus $(n=4)$ and fundus $(n=2)$.

Usually the H pylori status can be evaluated by means of a rapid urease test and/or histology within the initial endoscopic procedure. In those cases with a negative result, additional serological testing may be recommended with respect to an unknown antibiotic pretreatment or a secondary loss of the bacterium by tumour progression.

The stage of gastric lymphoma is usually described by the Musshoff classification for extranodal lymphoma (29) and its modification of stage EI by Radaszkiewicz et al (26) (Table 2). More recently, another classification system has been proposed - the Lugano classification (30). The prognostically important differentiation of stages EI1, EI2 and EII1 in both classification systems requires the use of endoscopic ultrasound, at least if a nonsurgical approach is favoured. It is the only morphological procedure that is able to visualize the different layers of the gastric wall and the perigastric lymph nodes (Figures 2 and 3 ). There is some evidence from a small series that success or failure of $\mathrm{H}$ pylori eradication therapy can be predicted by endoscopic ultrasound (31). In a prospective study of 77 patients with newly diagnosed gastric lymphoma, endoscopic ultrasound correctly predicted the depth of tumour infiltration (stage EI1 versus EI2) and the lymph node status (stage EI versus EII1) in 78\% and 75\%, respectively, compared with the gold standard of the pathohistological stage of the resected specimen (32). The main source of error was 'positive' lymph nodes in $21 \%$ of patients that were found at histology to be inflammatory reactions and not neoplastic changes. Thus, the diagnostic accuracy of endoscopic ultrasound is good, but not optimal. It may be further improved when endosonographic-guided puncture is available in the future. Also, the value of miniechoendoscopes has to be evaluated in this field.

\section{THERAPY}

Options in the treatment of gastric lymphoma include $H$ pylori eradication, surgical resection, radiation, chemotherapy and combinations of these modalities.

The convincing evidence for a pathogenetic role of $\mathrm{H} p \mathrm{p}$ lori infection, as pointed out above, inevitably involved a therapeutic effort. In 1993, Wotherspoon et al (33) reported a complete regression of low grade lymphoma following successful $\mathrm{H}$ pylori eradication in five-sixths of cases. Since then, several case reports and some prospective trials have confirmed this observation (33-46) (Table 3). The success rate of this approach is about $80 \%$. Usually, endoscopic and/or histological lymphoma regression occurs within one to three months; however, it may be delayed in individual cases. An interview of an international expert proved that a wait-and-see attitude for six to 18 months is justifiable, provided that there is no sign of disease progression $(\mathrm{H}$ Boot, personal communication). The majority of experts define treatment failure as lymphoma being present one year after successful eradication of $H$ pylori.

Undoubtedly, the eradication of $\mathrm{H}$ pylori represents a fascinating therapeutic option in low grade lymphoma of stage EI. However, the ultimate value of this principle will need to be further evaluated, because there are still many open questions: 
- What types of processes are involved in the lymphoma regression? Apoptosis? Differentiation?

- Which parameters indicate autonomous tumour growth and which criteria can predict the success of eradication therapy (Figure 1)?

- How often does lymphoma relapse? Is recurrence regularly accompanied by $H$ pylori reinfection?

- What is the risk of high malignant transformation?

- What is the significance of persisting monoclonal B cells found in a considerable percentage of patients with histologically, completely regressed lymphoma $(46,47)$ ?

These aspects clearly underline that, despite its simplicity and unexpected individual successes $(48,49), \mathrm{H}$ pylori eradication therapy in gastric lymphoma needs to be evaluated in clinical trials offering adequate diagnosis and close long term follow-up. Assuming that the disease is cured seems premature.

Until very recently, surgery was the standard procedure in gastric lymphoma or was a regular component of combined treatment modalities. The arguments for a surgical approach are as follows:

- Surgery provides precise histological classification and staging.

- Surgical resection (R0 resection) is a highly curative option in localized tumours. Five-year survival rates in stage EI were found to be as high as $85 \%$ to $100 \%$ $(25,26,50-53)$. R0 resection has also proved to be a relevant prognostic factor in retrospective and prospective studies $(52,54-56)$.

- Surgery is the most frequent treatment modality used so far and is also the treatment that doctors are most familiar with in cases of gastric lymphoma. In a meta-analysis of 80 studies with 3528 patients, a surgical approach was performed in $83 \%$ of patients (56). Only $17 \%$ of the patients were treated exclusively by radiation and/or chemotherapy. Five-year survival rates were significantly higher in surgically treated patients (60\% to $64 \%$ ) than in those treated with a conservative strategy (34\% to $44 \%)$.

- Surgery avoids complications, such as perforation or hemorrhage, that may occur in primary radiochemotherapy. This risk has, however, been overestimated for some time now $(57-59)$ and is probably not higher than the postoperative mortality rate.

- Surgery may be the patient's preference.

In recent years, opinion has increasingly swung toward primary radiotherapy or chemotherapy. The arguments for a nonsurgical therapeutic approach follow:

- Due to better endoscopic bioptic techniques and the introduction of endoscopic ultrasound, there is no need for surgery for diagnostic reasons. Possible limitations, as pointed out above, have to be kept in mind.
- The possibility of organ preservation contributes to a better quality of life.

- There is evidence from some recent studies for a high efficacy of conservative strategies in gastric lymphoma (57-65). These have, however, been hardly comparative analyses. The multicentre study by Koch et al (64) left it to each centre's discretion to choose surgical resection or primary conservative treatment in stages EI and EII. With reservations of possible bias, the equivalence of surgical and conservative strategies is nevertheless remarkable.

- Given the risk of extragastric recurrence or dissemination following surgery for high grade lymphoma, systemic chemotherapy is indicated.

- A nonsurgical treatment may be the patient's preference.

The decision for a treatment strategy combining local therapy (surgical resection or radiation) with systemic chemotherapy seems too logical, at least for advanced stages and high grade lymphoma. The majority of studies have chosen such an approach (56). In the German and Austrian prospective multicentre trial, surgery was the initial treatment in stages EI and EII (except for low grade lymphoma of stage EI, which received $H$ pylori eradication therapy). Stratified according to pathohistological stage and grade of malignancy, patients were postoperatively treated by chemotherapy and/or radiotherapy, or entered into follow-up observation. Complete remission was achieved in $96 \%$ of patients (28). Based on an intention-to-treat analysis, R0 resection was significantly superior to $\mathrm{R} 1 / 2$ resection with respect to overall survival.

\section{FUTURE THERAPEUTIC ASPECTS}

There is no standardized, generally accepted therapy for gastric lymphoma; the search for the best therapeutic approach must continue. The main clinical challenge for the future is to clarify whether surgery remains an option or whether it can be replaced with conservative treatment modalities offering equivalent efficacy and better quality of life. A satisfactory answer to this question can be best provided by a prospective, randomized study. An European multicentre trial was initiated in 1998.

\section{REFERENCES}

1. Dawson IMP, Cornes JS, Morson BC. Primary malignant lymphoid tumours of the intestinal tract: report of 37 cases with a study of factors influencing prognosis. Br J Surg 1961;49:80-9.

2. Herrmann R, Panahon AM, Barcos MP, Walsh D, Stutzman L. Gastrointestinal involvement in non-Hodgkin's lymphoma. Cancer 1980;46:215-22.

3. Lewin KJ, Ranchod M, Dorfman RF. Lymphomas of the gastrointestinal tract: a study of 117 cases presenting with gastrointestinal disease. Cancer 1978;42:693-707.

4. Isaacson PG, Spencer J. Malignant lymphoma of mucosa-associated lymphoid tissue. Histopathology 1987;11:445-62.

5. Isaacson PG, Spencer J, Wright DH. Classifying primary gut lymphomas. Lancet 1988;12:1148-9.

6. Fischbach W, Kestel W, Kirchner T, Mössner J, Wilms K. Malignant lymphomas of the upper gastrointestinal tract. Results of a prospective study in 103 patients. Cancer 1992;70:1075-80. 
7. Harris NL, Jaffe ES, Stein H, et al. A revised EuropeanAmerican classification of lymphoid neoplasms: a proposal from the International Lymphoma Study Group. Blood 1994;84:1361-92.

8. Stolte M, Eidt S. Lymphoid follicles in antral mucosa: Immune response to Campylobacter pylori? J Clin Pathol 1989;42:1269-71.

9. Wyatt JI, Rathbone BJ. Immune response of the gastric mucosa to Campylobacter pylori. Scand J Gastroenterol 1988;23(Suppl 142):135-40.

10. Kirchner TH, Melber A, Fischbach W, Heilmann KL, Müller-Hermelink HK. Immunohistological patterns of the local immune response in Helicobacter pylori gastritis. In: Malfertheiner P, Ditschuneit H, eds. Helicobacter pylori, Gastritis and Peptic Ulcer. Berlin: Springer-Verlag, 1990:213-22.

11. Stolte M. Helicobacter pylori gastritis and gastric MALT-lymphoma. Lancet 1992;339:745-6.

12. Wotherspoon AC, Ortiz-Hildalgo C, Falzon MR, Isaacson PG. Helicobacter pylori-associated gastritis and primary B-cell gastric lymphoma. Lancet 1991;338:1175-6.

13. Eidt S, Stolte M, Fischer R. Helicobacter pylori gastritis and gastric non-Hodgkin's lymphoma. J Clin Pathol 1994;47:436-9.

14. Eck M, Schmausser W, Haas R, et al. MALT-type lymphoma of the stomach is associated with Helicobacter pylori strains expressing the CagA protein. Gastroenterology 1997;112:1482-6.

15. Doglioni C, Wotherspoon AC, Moschini A, de Boni M, Isaacson PG. High incidence of primary gastric lymphoma in northeastern Italy. Lancet 1992:339:834-5.

16. Parsonnet J, Hansen S, Rodriguez L, et al. Helicobacter pylori infection and gastric lymphoma. N Engl J Med 1994;330:1267-71.

17. Greiner A, Marx A, Heesemann J, Leebmann J, Schmausser B, Müller-Hermelink HK. Idiotype identity in a MALT-type lymphoma and B cells in Helicobacter pylori associated chronic gastritis. Lab Investigation 1994;70:572-8.

18. Hussell T, Isaacson PG, Crabtree JE, Spencer J. The response of cells from low-grade B-cell gastric lymphomas of mucosa-associated lymphoid tissue to Helicobacter pylori. Lancet 1993;342:571-4.

19. Hussell T, Isaacson PG, Crabtree JE, Spencer J. Helicobacter pylori-specific tumor-infiltrating $\mathrm{T}$ cells provide contact dependent help for the growth of malignant $B$ cells in low-grade gastric lymphoma of mucosa-associated lymphoid tissue. J Pathol $1996 ; 178: 122-7$

20. Enno A, O'Rourke J, Howlett R, et al. MALToma-like lesions in the murine gastric mucosa after long-term infection with Helicobacter felis - a mouse model of Helicobacter pylori-induced gastric lymphoma. Am J Pathol 1995;147:217-22.

21. Enno A, O'Rourke J, Howlett CR, Lee A. Mouse to mouse resuscitation of low-grade MALT lymphoma induced by prolonged Helicobacter infection. A preliminary study of transplanted tumors. Gastroenterology 1996;110:A536.

22. Ott G, Katzenberger T, Greiner A, et al. The t(11;18)(q21;q21) chromosome translocation is a frequent and specific aberration in low-grade but not high-grade malignant non-Hodgkin's lymphomas of the mucosa-associated lymphoid tissue (MALT-) type. Cancer Res 1997;57:3944-8

23. Stolte M, Kroher G, Meining A, Morgner A, Bayerdörffer E, Bethke B. A comparison of Helicobacter pylori and H. heilmannii gastritis. A matched control study involving 404 patients. Scand J Gastroenterol 1997;32:28-33.

24. Kolve ME, Greiner A, Müller-Hermelink HK, Wilms K, Fischbach W. Eradication of Helicobacter pylori (Hp) in gastric MALT-type lymphoma is still an experimental therapy. Gastroenterology 1997;112:A594

25. Cogliatti SB, Schmid U, Schumacher U, et al. Primary B-cell gastric lymphoma: a clinicopathological study of 145 patients. Gastroenterology 1991;101:1159-70.

26. Radaszkiewicz T, Dragosics B, Bauer P. Gastrointestinal malignant lymphomas of the mucosa-associated lymphoid tissue: Factors relevant to prognosis. Gastroenterology 1992;102:1628-38.

27. Kolve M, Fischbach W, Greiner A, Wilms K. Differences in endoscopic and clinicopathological features of primary and secondary gastric non-Hodgkin's lymphoma. German Gastrointestinal Lymphoma Study Group. Gastrointest Endosc 1999;43:307-15.

28. Fischbach W, Kolve M-E, Dragosics B, et al. Histology and stage stratified therapy offers promising results in primary gastric non-Hodgkin's lymphoma: experiences of the GermanAustrian prospective multicenter trial. Gastroenterology 1998;114:A595. (Abst)
29. Musshoff K. [Clinical staging classification of non-Hodgkin's lymphoma]. Strahlentherapie 1977;153:218-21.

30. Rohatiner A, d'Amore F, Coiffier B, et al. Report on a workshop convened to discuss the pathological and staging classifications of gastrointestinal tract lymphoma. Ann Oncol 1994;5:397-400.

31. Sackmann M, Morgner A, Rudolph B, et al. Regression of gastric MALT lymphoma after eradication of Helicobacter pylori is predicted by endosonographic staging. MALT Lymphoma Study Group. Gastroenterology 1997;113:1087-90.

32. Fischbach W, Kolve M-E, Ohmann C. Value of endoscopic ultrasound (EUS) in staging primary gastric lymphoma: results of the German-Austrian prospective multicenter trial. Endoscopy 1995;27:534. (Abst)

33. Wotherspoon AC, Doglioni C, Isaacson PG. Low-grade gastric B-cell lymphoma of mucosa-associated lymphoid tissue (MALT): a disease. Histopathology 1992;20:29-34.

34. Weber DM, Dimopoulos MA, Anandu DP, Pugh WC, Steinbach G. Regression of gastric lymphoma of mucosa-associated lymphoid tissue with antibiotic therapy for Helicobacter pylori. Gastroenterology 1994;107:1835-8

35. Pesch S, Müller W, Borchard F, Peters U. [Low malignancy MALT lymphoma of the stomach: $H$. pylori eradication as a therapeutic concept]? Z Gastroenterol 1994;32:684-7.

36. Fetscher S, Bayerdörffer E, Finke J. [78-year-old patient with chronic epigastric pain]. Internist 1995;36:1182-9.

37. Cammarota G, Montalto M, Tursi A, Vecchio FM, Fedeli G, Gasbarrini G. Helicobacter pylori reinfection and rapid relapse of low-grade B-cell gastric lymphoma. Lancet 1995;345:192.

38. Bayerdörffer E, Neubauer A, Rudolph B, et al. Regression of primary gastric lymphoma of mucosa-associated lymphoid tissue type after cure of Helicobacter pylori infection. MALT Lymphoma Study Group. Lancet 1995;345:1591-4.

39. Morgner A, Bayerdörffer E, Neubauer A, et al. Cure of Helicobacter pylori infection in 125 patients with primary gastric low-grade MALT lymphoma. Gastroenterology 1998;114:A814. (Abst)

40. Roggero E, Zucca E, Pinotti G, et al. Eradication of Helicobacter pylori infection in primary low-grade gastric lymphoma of mucosa-associated lymphoid tissue. Ann Intern Med 1995;122:767-9.

41. Savio A, Franzin G, Wotherspoon AC, et al. Longterm effect of anti-Helicobacter pylori therapy on gastric MALT lymphoma. Histological and molecular evaluation of 15 cases. Gut 1995;37:A246. (Abst)

42. Carlson SJ, Yokoo H, Vanagunas A. Progression of gastritis to monoclonal B-cell lymphoma with resolution and recurrence following eradication of Helicobacter pylori. JAMA 1996;275:937-9.

43. Montalban C, Manzanal A, Boixeda D, et al. Helicobacter pylori eradication for the treatment of low-grade gastric MALT-lymphoma: Follow-up together with sequential molecular studies. Ann Oncol 1997;8(Suppl 2):37-9.

44. Tassinari D, Sartori S, Cangiotti C, et al. [Regression of primary gastric lymphoma after treatment with ranitidine]. Recenti Prog Med 1998;88:179-80.

45. Tsai MH, Hsu YH, Yang KC, et al. Low-grade gastric mucosa-associated lymphoid tissue lymphoma (MALToma) Clinical characteristics, endoscopic features, treatments and outcomes. An analysis of eight cases. Gastroenterol J Taiwan 1997;14:7-17.

46. Nobre-Leitao C, Lage $\mathrm{P}$, Cravo M, et al. Treatment of gastric MALT lymphoma by Helicobacter pylori eradication: a study controlled by endoscopic ultrasonography. Am J Gastroenterol 1998;93:732-6.

47. Neubauer A, Thiede C, Morgner A, et al. Cure of Helicobacter pylori infection and duration of remission of low-grade gastric mucosa-associated lymphoid tissue lymphoma. J Natl Cancer Inst 1997;89:1350-5.

48. Fischbach W, Tacke W, Greiner A, Müller-Hermelink HK. Regression of immunoproliferative small intestinal disease after eradication of Helicobacter pylori. Lancet 1997;349:31-2.

49. Fischbach W, Engemann R, Stolte M. A pitfall in assessing gastric lymphoma after eradication of Helicobacter pylori. $\mathrm{N}$ Engl J Med 1997;336:1529-30.

50. Rackner VL, Thirlby RC, Ryan JA Jr. Role of surgery in multimodality therapy for gastrointestinal lymphoma. Am J Surg $1991 ; 161: 570-5$. 
51. Roukos DH, Hottenrott C, Encke A, Baltogiannis G, Casioumis D. Primary gastric lymphomas: a clinicopathologic study with literature review. Surgical Oncol 1994;3:115-25.

52. Montalban C, Castrillo JM, Abraira V, et al. Gastric B-cell mucosa-associated lymphoid tissue (MALT) lymphoma: Clinicopathological study and evaluation of the prognostic factors in 143 patients. Ann Oncol 1995;6:355-62.

53. Sano T, Sasako M, Kinoshita T, et al. Total gastrectomy for primary gastric lymphoma at stages IE and IIE: a prospective study of fifty cases. Surgery 1997;121:501-5.

54. Bozzetti F, Audisio RA, Giardini R. Role of surgery in patients with primary non-Hodgkin's lymphoma of the stomach: an old problem revisited. Br J Surg 1993;80:1101-6.

55. Ruskone-Fourmestraux A, Aegerter P, Delmer A, Brousse N, Galian A, Rambaud JC. Primary digestive tract lymphoma: a prospective multicentric study of 91 patients. Groupe d'Etude des Lymphomes Digestifs. Gastroenterology 1993;105:1662-72.

56. Brands F, Mönig SP, Raab M. Treatment and prognosis of gastric lymphoma. Eur J Surg 1997;163:803-13.

57. Gobbi PG, Dionigi P, Barbieri F, et al. The role of surgery in the multimodal treatment of primary gastric non-Hodgkin's lymphomas. A report of 76 cases and review of the literature. Cancer 1990;65:2528-36.

58. Taal BG, Burgers JM, van Heerde P, Hart AA, Somers R. The clinical spectrum and treatment of primary non-Hodgkin's lymphoma of the stomach. Ann Oncol 1993;4:839-46.

59. Rabbi C, Aitini E, Cavazzini G, et al. Stomach preservation in lowand high-grade primary gastric lymphomas: preliminary results. Haematologica 1996;81:15-9.

60. Haim N, Leviov M, Ben-Arieh Y, et al. Intermediate and high-grade gastric non-Hodgkin's lymphoma: a prospective study of non-surgical treatment with primary chemotherapy, with or without radiotherapy. Leuk Lymphoma 1995;17:321-6.

61. Maor MH, Velasquez WS, Fuller LM, Silvermintz KB. Stomach conservation in stages IE and IIE gastric non-Hodgkin's lymphoma. J Clin Oncol 1990;8:266-71.

62. Solidoro A, Payet C, Sanchez-Lihon J, Montalbetti JA. Gastric lymphomas: chemotherapy as a primary treatment. Semin Surg Oncol 1990;6:218-25.

63. Sonnen R, Calavrezos A, Grimm HA, Kuse R. [Combined conservative treatment of localized stomach lymphoma]. Dtsch med Wochenschr 1994;119:863-8.

64. Koch P, Grothaus-Pinke B, Hiddemann W, et al. Primary lymphoma of the stomach: three-year results of a prospective multicenter study. The German Multicenter Study Group on GI-NHL. Ann Oncol 1997;8(Suppl 1):85-8.

65. Schechter NR, Portlock CS, Yahalom J. Treatment of mucosa-associated lymphoid tissue lymphoma of the stomach with radiation alone. J Clin Oncol 1998;16:1916-21. 


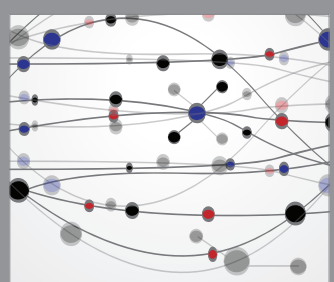

The Scientific World Journal
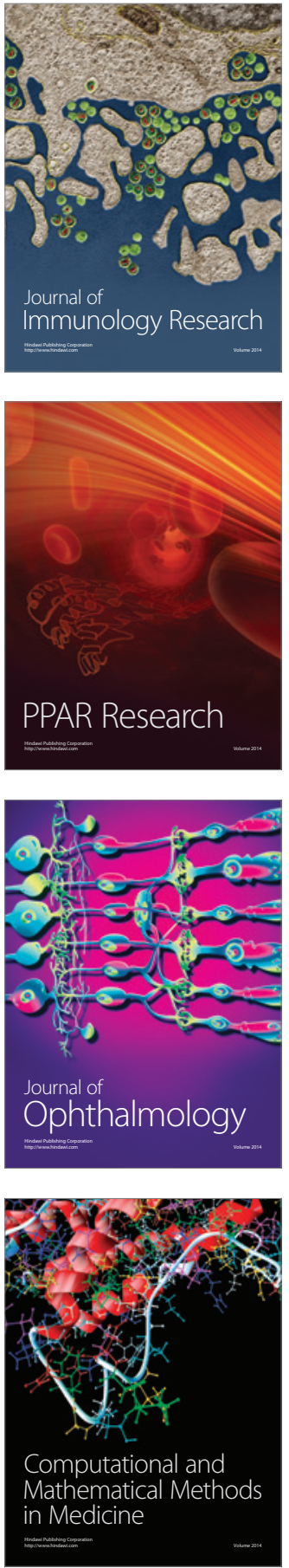

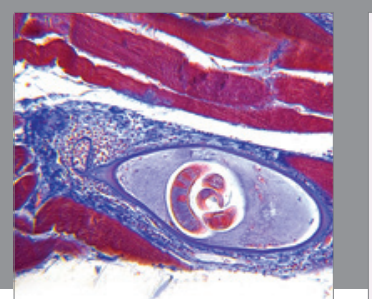

Gastroenterology Research and Practice

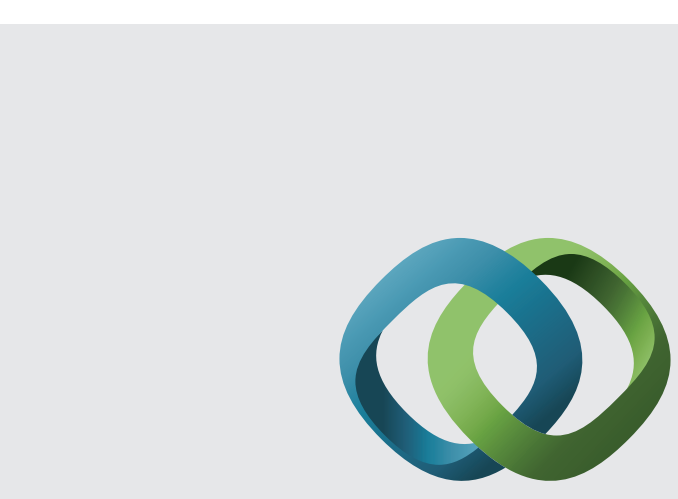

\section{Hindawi}

Submit your manuscripts at

http://www.hindawi.com
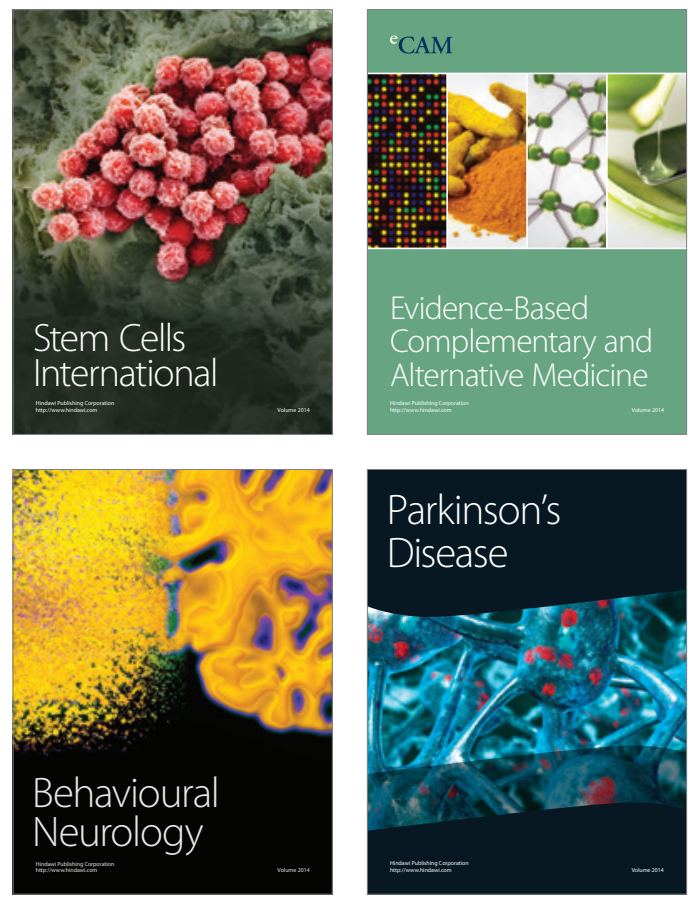
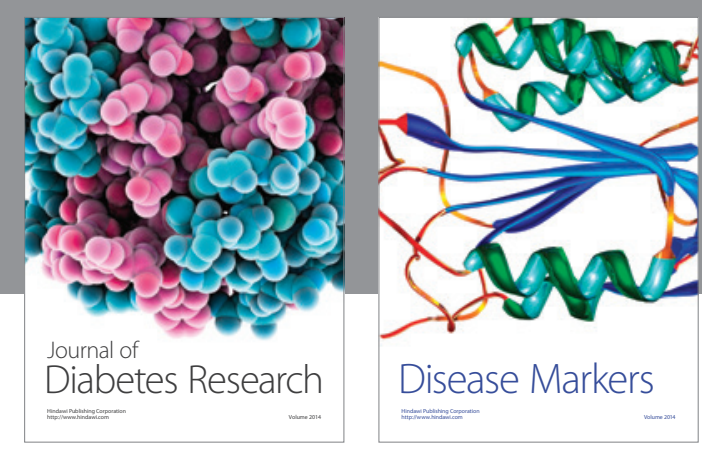

Disease Markers
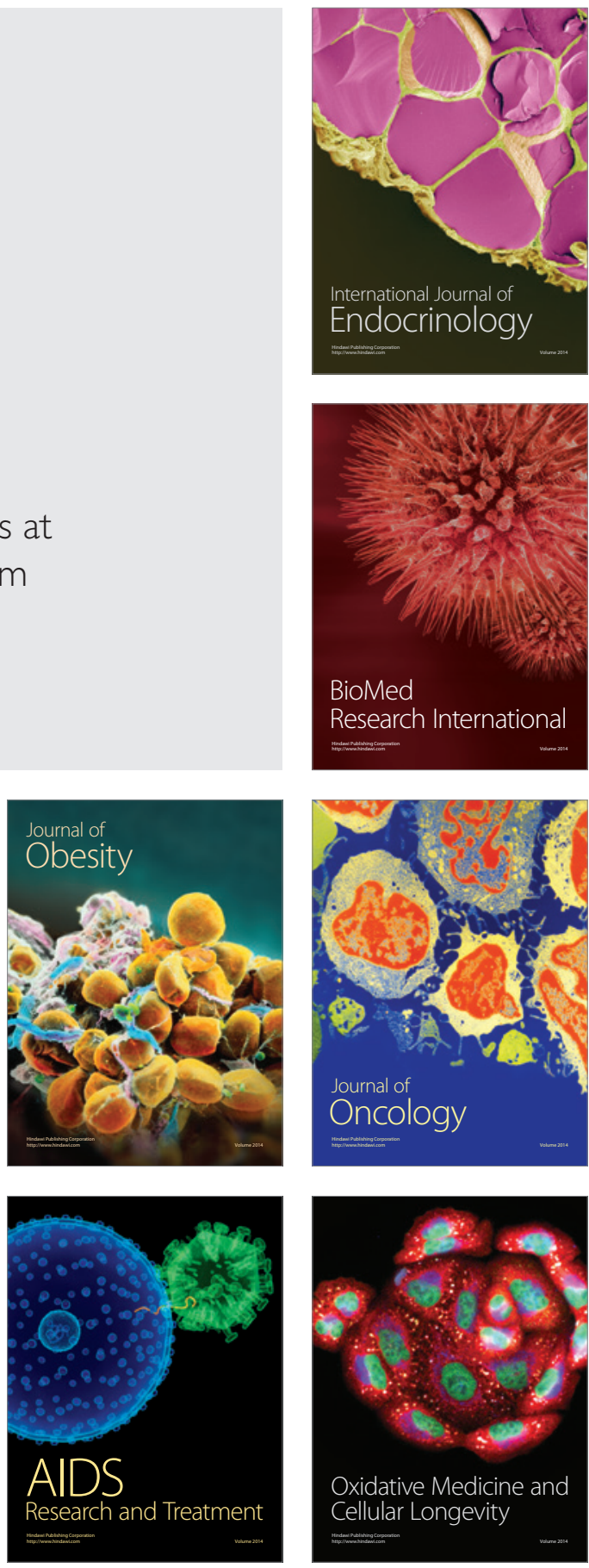